\title{
Composition and distribution of fishes from the Perequê-Açu river basin, Paraty, Rio de Janeiro, Southeastern Brazil
}

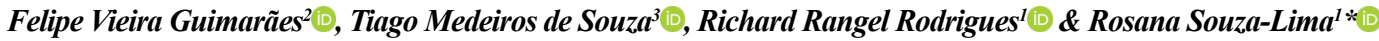 \\ ${ }^{1}$ Universidade do Estado do Rio de Janeiro, Laboratório de Estudos de Peixes, Faculdade de Formação de \\ Professores, Rua Dr. Francisco Portela, 1470, Patronato, São Gonçalo, RJ, Brasil. \\ ${ }^{2}$ Universidade Federal do Espírito Santo, Programa de Pós-graduação em Biologia Animal, Campus \\ Goiabeiras, Av. Fernando Ferrari, 514, Goiabeiras, Vitória, ES, Brasil. \\ ${ }^{3}$ Instituto de Previdência e Assistência dos Servidores de São Gonçalo, Rua Cel. Serrado, 1000, Zé Garoto, São \\ Gonçalo, RJ, Brasil. \\ Corresponding author: Rosana Souza-Lima, e-mail: rosanasouzalima@gmail.com
}

GUIMARÃES, F.V., SOUZA, T.M., RODRIGUES, R.R., SOUZA-LIMA, R. Composition and distribution of fishes from the Perequê-Açu river basin, Paraty, Rio de Janeiro, Southeastern Brazil. Biota Neotropica 21(2): e20201096. https://doi.org/10.1590/1676-0611-BN-2020-1096

\begin{abstract}
The large number of less-known coastal drainages in the Atlantic Forest still represents an important gap in the knowledge of ichthyofauna. It is evaluated the taxonomic diversity, frequency and constancy of occurrence, and the distribution of species in the various segments of the Perequê-Açu river basin, state of Rio de Janeiro, Brazil. Twelve sampling campaigns resulted in 13,423 individuals, belonging to seven orders, 10 families, 21 genera, and 23 native species. Cyprinodontiformes and Siluriformes represented about $87.2 \%$ of the total abundance, mainly due to the contribution of Phalloceros anisophallos and Schizolecis guntheri, which account for $63.2 \%$ of the total sampled individuals. The analysis of constancy of occurrence reveals that $78.3 \%$ of the drainage species are residents, with approximately $93 \%$ of the residents of the Carrasquinho River sub-basin. The Sertões River sub-basin had the largest number of species in total: 18. The rarefaction curve did not reach an asymptote, although Chao 2 and bootstrap estimate the richness of 23.9 species and 23.7 species, respectively. The results of PERMANOVA, PCoA, and SIMPER indicate that the fish composition along the catchment is not homogeneous. The conservation status of species is also discussed, regionally, nationally, and globally.

Keywords: Atlantic Rainforest, Conservation, Freshwater fishes, Inventory, Serra da Bocaina National Park.

\section{Composição e distribuição de peixes da bacia do rio Perequê-Açu, Paraty, Rio de Janeiro, Sudeste do Brasil}

Resumo: O grande número de drenagens costeiras pouco estudadas na Mata Atlântica ainda representa uma lacuna importante no conhecimento da ictiofauna. Avalia-se aqui a diversidade taxonômica, frequência e constância de ocorrência e a distribuição das espécies nos vários segmentos da bacia do rio Perequê-Açu, estado do Rio de Janeiro, Brasil. Doze campanhas de amostragem resultaram em 13.423 indivíduos, pertencentes a sete ordens, 10 famílias, 21 gêneros e 23 espécies nativas. Cyprinodontiformes e Siluriformes representaram cerca de 87,2\% da abundância total, devido sobretudo à contribuição de Phalloceros anisophallos e Schizolecis guntheri, que respondem por $63,2 \%$ do total de indivíduos amostrados. A análise de constância de ocorrência revela que 78,3\% das espécies da drenagem são residentes, sendo cerca de $93 \%$ dos residentes da sub-bacia do rio Carrasquinho. A sub-bacia do rio Sertões apresentou o maior número de espécies no total: 18. A curva de rarefação não atingiu uma assíntota, embora Chao 2 e bootstrap estimem a riqueza de 23,9 espécies e 23,7 espécies, respectivamente. Os resultados de PERMANOVA, PCoA e SIMPER indicam que a composição dos peixes ao longo da bacia hidrográfica não é homogênea. Discute-se, ainda, o status de conservação das espécies, regional, nacional e globalmente.

Palavras-chave: Conservação, Inventário, Mata Atlântica, Parque Nacional da Serra da Bocaina, Peixes de água doce. 


\section{Introduction}

The coastal area in the south of Rio de Janeiro state is characterized by presenting relatively narrow stretches of flat terrains located at the base of Serra do Mar (Guerra et al. 2013). The eastern slope of these mountains, the eastern edge of the Brazilian Plateau, is full of relatively short and fast rivers that generally run through a few dozen kilometers till the Atlantic Ocean (Andreata et al. 2002, Buckup 2011, Guerra et al. 2013). Ilha Grande Bay Hydrographic Region consists of independent river basins located in the municipalities of Angra dos Reis and Paraty. These areas are expected to exhibit relatively low diversity but high levels of endemism (Bizerril 1994, Ribeiro 2006, Abilhoa et al. 2011, Buckup 2011). Abell et al. (2008) called this as Ecoregion 325 , Fluminense, with endemism rates of $29-39 \%$ (at least 28 endemic freshwater fish species). However, most studies approach marine environments (e.g. Andreata et al. 2002, Ferreira et al. 2007, Gaelzer et al. 2007, Amaral et al. 2018), while few studies about freshwater fishes are available (e.g. São-Thiago 1990).

Recent studies (Guerra et al. 2013) show the environmental fragility of this area. The first major impacts in this region were due to urban growth occurred after the construction of Rio-Santos (BR-101), a great scenic beauty road that connects the two biggest South American cities, São Paulo and Rio de Janeiro. Now, the newly paved stretch of Paraty-Cunha road (RJ-165) should increase the population density in this region, increasing negative impacts on watercourses, a fundamental resource both for the good quality of life in the region and for the maintenance of economic activities in that area of the state (FormigaJohnsson 2015). Decree No. 5,092 / 2004 (Brasil 2004) recommended to a committee working in a Project for Conservation and Sustainable Use of Brazilian Biological Diversity (Probio), the evaluation of priority areas for conservation in the coastal and marine areas of Brazil; one of the extremely high priorities selected areas was exactly Ilha Grande Bay (Creed et al. 2007), although just its marine area. However, the lack of knowledge about the hydrographic basins of this region shows that we are not even able to assess the conservation status of these drainages. The most worrying aspect of this is that in addition to an important ecological role, much of the coastal region in the south of the state is supplied by these rivers, which play a fundamental role in the quality of life and economic activities developed in the region, including ecotourism and adventure tourism (Formiga-Johnsson et al. 2015). Deforestation and pollution caused by inadequate tourism infrastructure intensify the water demands, the uses of rivers and beaches, and is a specific environmental problem of this region (Gaelzer et al. 2007).

Ichthyofauna surveys are extremely important for management and conservation of freshwater fishes (Azevedo-Santos et al. 2019), serving as a first step as they provide the basis for future studies in other areas such as ecology, conservation, and systematics (Frota et al. 2019), as well as being the basis for the description of new species. The Neotropical region has the largest number of freshwater fish species on the planet, with circa of 5,000 species of fishes described, about 3,000 of them in Brazil (Reis et al. 2016). Buckup et al. (2007) pointed out that the number of descriptions of freshwater fish species has been increasing by over $20 \%$ annually, especially in the South and Southeast regions of Brazil. According to Langeani et al. (2009), such diversity reflects the complexity of habitat and the life history of freshwater fishes.

The evaluation presented here is a result of a wildlife monitoring project developed during the paving works of the Rio de Janeiro stretch of Paraty-Cunha road (RJ 165), which crosses Serra da Bocaina National Park. The purpose of the monitoring project was to identify specimens from fauna and flora and potential problems affecting them caused by the engineering work. Thus, the objective of this paper is to inventory the fish species of the Perequê-Açu river basin and its sub-basins, assess their conservation status, and identify the presence of resident, rare and accessory species. As the complexity of the community along the river is expected to increase from upstream to downstream (Vannote et al. 1980), we seek to determine whether the fauna of the high, medium and low stretches of each sub-basin are related to each other.

\section{Material and Methods}

\section{Study area}

The Perequê-Açu river basin (Figure 1) is part of the Ilha Grande Bay Hydrographic Region. Most of the headwaters of the basin are sheltered within Serra da Bocaina National Park (PNSB), the largest Brazilian coastal Park (104,000 hectares; IBAMA 2001), spread between the states of Rio de Janeiro and São Paulo. The Park presents dense ombrophilous forest, mixed ombrophilous forest, and subtropical highland grasslands, with altitudes that range from zero to $2,088 \mathrm{~m}$, which confers to this conservation unit a great diversity and complexity of environments (IBAMA 2001). The climate in the region is temperate super humid, with annual precipitation of $1800 \mathrm{~mm}$. The average temperature is around $16^{\circ} \mathrm{C}$, with high variation between altitude extremes: $38^{\circ} \mathrm{C}$ in lowland areas and $0{ }^{\circ} \mathrm{C}$ in the highest areas (Guimarães et al. 2000).

The name by which this drainage is known, Perequê-Açu, refers only to the resulting river in the final stretch of this basin. For descriptive and analytic purposes, this drainage was thus separated into five sub-basins that represents its main tributaries, hereafter referred as Sertões river sub-basin (SBS), Pedra Branca river sub-basin (SBP), Muricana river sub-basin (SBM), Carrasquinho river sub-basin (SBC) and PerequêAçu River itself (SBA).

\section{Sampling and data analyses}

Twelve samplings of fishes were performed from June 2013 to November 2016 under collecting permit 248/2013 (Ibama, Process 02001.003937/2008-18). Twenty-four georeferenced locations (Table 1) were sampled for 45 minutes each site, in distinct environments with altitudes ranging from $9 \mathrm{~m}$ to $1,044 \mathrm{~m}$ in stretches of variable length. We used hand nets, sieves, and two trawls: $1.5 \mathrm{~m}$ long $\mathrm{x} 1 \mathrm{~m}$ wide, with $5 \mathrm{~mm}$ mesh, and $3 \mathrm{~m}$ long x $2 \mathrm{~m}$ trawl, with $5 \mathrm{~mm}$ mesh. Most individuals were identified in the field, counted, and released. Individuals with taxonomic doubts were anesthetized in a $10 \%$ eugenol solution, immediately placed in a $10 \%$ formalin solution, and then permanently stored in $70 \%$ alcohol. Specimens for genetic analysis were immediately deposited in absolute ethanol. The material was deposited in the fish collection at Faculdade de Formação de Professores, Universidade do Estado do Rio de Janeiro (FFP/UERJ) and voucher material was deposited in the ichthyological collection of Museu Nacional, Universidade Federal do Rio de Janeiro (MNRJ). Taxonomic identification followed specialized literature and classification adopted is summarized in Fricke et al. (2020). 


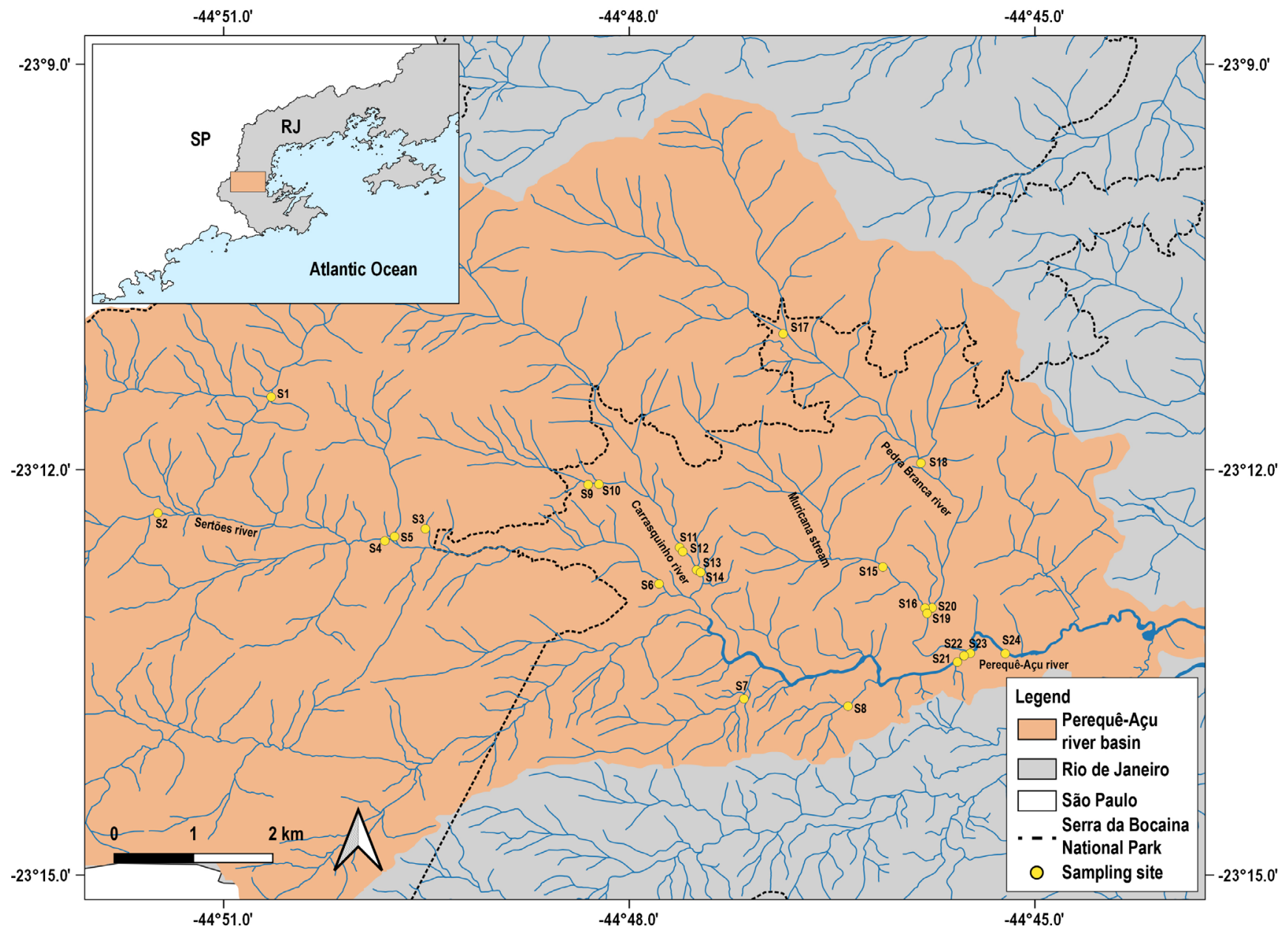

Figure 1. Sampled sites in the Perequê-Açu river basin. $\mathrm{SP}=$ São Paulo; RJ = Rio de Janeiro.

A constancy of occurrence index (Dajoz 1983) was applied to analyze the total amount of species obtained in the 12 campaign samples and for the total obtained in each sub-basin to verify the frequency of species in the drainage and in each group of sites. According to this index, constant species are present in more than $50 \%$ of the samples, accessory species are present in 25 to $50 \%$ and rare species are present in less than $25 \%$. The number of species collected was verified using a rarefaction curve, which is a plot of the number of species as a function of the number of samples, to standardize the species richness expected to be found in a certain number of samples (Melo 2008). We calculated the bootstrap and Chao 2 species estimators, species extrapolation methods to verify whether the maximum number of species has already been sampled in the basin (Efron 1979, Gotelli \& Colwell 2011). Additionally, we applied four indices for each site to evaluate the structure of the ichthyofaunistic diversity: Shannon's diversity (H), Simpson's dominance (D), Pielou's equitability (J') and total richness (Simpson 1949, Pielou 1975, Krebs 1999, Magurran 2004).

Spatial variations on the ichthyofauna distribution among upper, middle, and lower sites of the basin followed Cavalheiro \& Fialho (2020), where further explanations on these procedures can be found. Once the abundances of the species were logtransformed, we performed an a priori Permutational Multivariate
Analysis of Variance (PERMANOVA), based on the Bray-Curtis dissimilarity index, to identify patterns of distribution of species, which if identified were plotted in a Principal Coordinates Analysis ( $\mathrm{PCoA})$ ordination graph, using the Bray-Curtis dissimilarity index (Legendre \& Legendre 1998). In order to further assess species distribution patterns in the basin, we performed a Similarity Percentage (SIMPER) analysis (Clarke 1993), identifying species that most contributed to dissimilarities between groups of upstream, middlestream and downstream sites.

The rarefaction curve, diversity indices, and species estimators were calculated using the statistical software PAST v. 4.03 (Hammer et al. 2001). The PERMANOVA and SIMPER analyses were performed using the software PRIMER 6.1 with PERMANOVA+ (Clarke \& Gorley 2006). The PCoA was performed using R Project for Statistical Computing v. 3.6.1 (R Core Team 2019), with the packages "ape" v. 5.4 (Paradis \& Schliep 2019) and "adespatial" v. 0.3-8 (Dray et al. 2020), at a confidence level of $95 \%(p<0.05)$. The map of the basin was developed in the software QGis v. 3.12 (QGIS Development Team 2020).

\section{Results}

A total of 13,423 specimens were sampled, belonging to seven orders, 10 families, 21 genera, and 23 species (Table 2; Figures 2-3). 
Table 1. Sampled localities in the Perequê-Açu river basin, Paraty, RJ. The sub-basin acronym, the acronym for each site, the name of the site, coordinates, and altitude are displayed. SBS $=$ Sub-basin of Sertões river; SBC $=$ Sub-basin of Carrasquinho river; $\mathrm{SBL}=\mathrm{Sub}-\mathrm{basin}$ of Laje river; $\mathrm{SBP}=$ Sub-basin of Pedra Branca river; SBA $=$ Sub-basin of Perequê-Açu river.

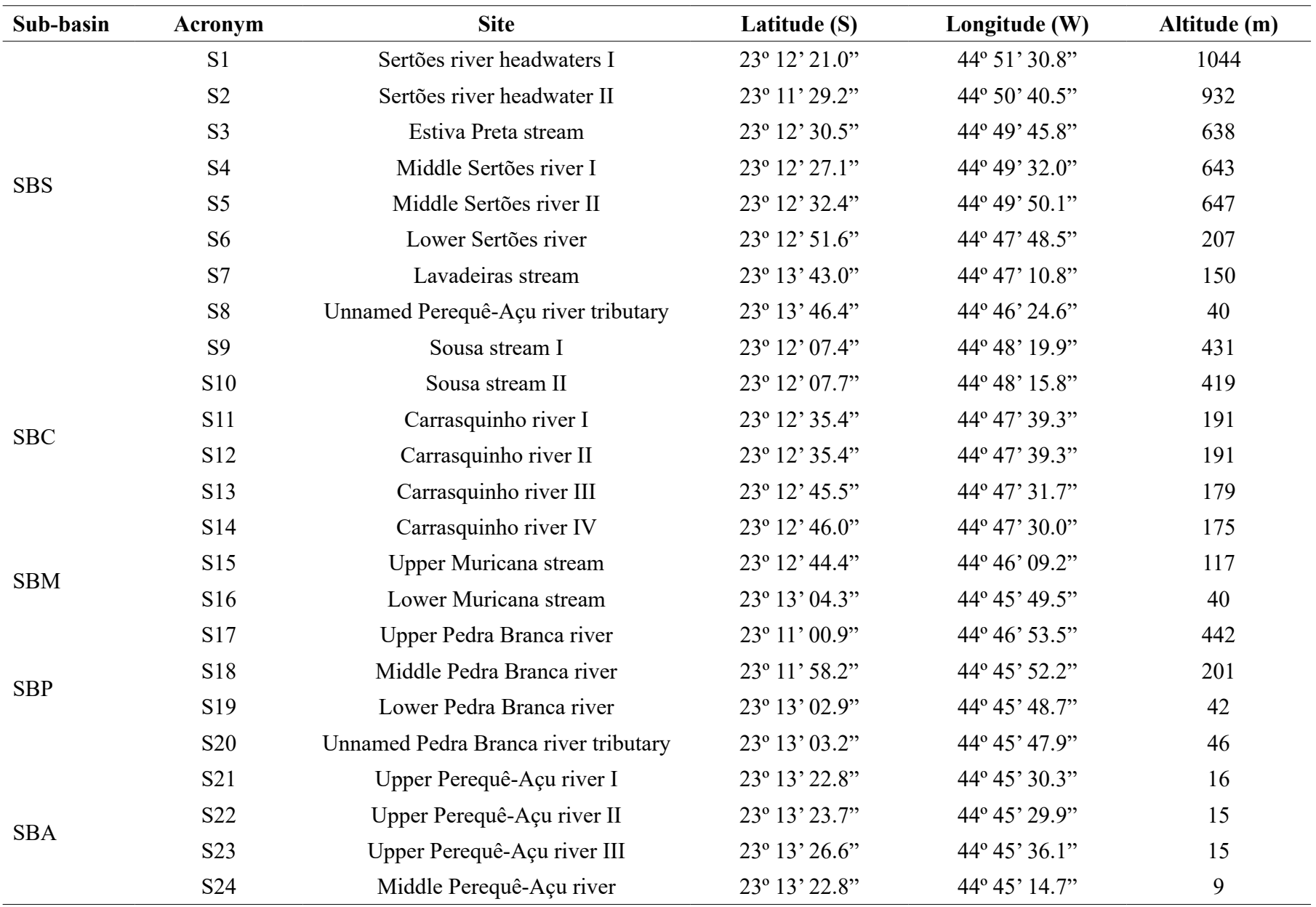

The most representative orders in abundance were Cyprinodontiformes (46.8\%) and Siluriformes (40.4\%), with 11,700 individuals (about $87.2 \%$ of the total sampled, Figure 4 ), due mainly to the contribution of the two most abundant species in the basin: Phalloceros anisophallos (n $=5,853$, Figure 3R-3S) and Schizolecis guntheri $(\mathrm{n}=2,636$, Figure 3L). These two species accounts for $63.2 \%$ of the sampled individuals. The order Siluriformes was the most taxonomically diverse, with 12 species, followed by Characiformes, with four species (17.4\%). Gymnotiformes and Mugiliformes were the least representative orders, presenting only one species each (4.3\%). Poeciliidae is the most representative of the families, contributing with $46.8 \%$ of individuals $(n=6,281)$, followed by Loricariidae $(n=4,725,35.2 \%)$ and Characidae $(n=1,474,11 \%$; Figure 4).

The constancy of occurrence index revealed that most species in the basin are constant (Deuterodon hastatus, D. intermedius, Hollandichthys multifasciatus, Bryconamericus ornaticeps, Acentronicthhys leptos, Rhamdia quelen, Rhamdioglanis transfasciatus, Hemipsilichthys nimius, Kronichthys heylandi, Neoplecostomus paraty, Schizolecis guntheri, Trichogenes longipinnis, Trichomycterus sp., Geophagus brasiliensis, Awaous tajasica, Eleotris pisonis, Phalloceros anisophallos, and P. harpagos, Figure 5), with about $78.3 \%(\mathrm{n}=18)$ of frequency in the 12 sampling campaigns, followed by the accessory $(13 \%, n=3)$ and rare species $(8.7 \%, n=2)$. Carrasquinho river sub-basin proportionally presented the highest percentage of resident species, about $93 \%$ of frequency $(\mathrm{n}=8)$, followed by Muricana stream $(70 \%, \mathrm{n}=7)$ and Sertões river $(55.5 \%, \mathrm{n}=10)$, the latter being also the sub-basin which presented the largest number of species in total: 18 .

The site with the highest richness and abundance $(\mathrm{S}=13, \mathrm{n}=$ 1,520) was S23, Upper Perequê-Açu river III (Table 3). Sertões river headwater I ( $\mathrm{S} 1)$ presented the lowest richness $(\mathrm{S}=2)$ and abundance $(\mathrm{n}=34)$. Estiva Preta stream (S3) presented the lowest dominance rates of the basin $(\mathrm{D}=0.197)$, as well as the highest values on diversity and evenness $\left(H^{\prime}=1.675, J^{\prime}=0.935\right)$. A near site, Middle Sertões river I $(\mathrm{S} 4)$, presented lower evenness $\left(\mathrm{J}^{\prime}=0.123\right)$, diversity $\left(\mathrm{H}^{\prime}=0.171\right)$, and high dominance values $(\mathrm{D}=0.932)$. The rarefaction curve did not reach an asymptote (Figure 6), even in the $95 \%$ confidence interval. The Chao 2 and bootstrap richness estimators estimate the richness of 23.9 species $( \pm 2.13)$ and 23.7 species, respectively. Information on the conservation status of the species can be seen in Table 2 . 
Table 2. Taxa sampled in the Perequê-Açu river basin, Paraty, RJ. The acronym used in analyses, relative frequency (\%) of the species, their conservation status, the category of constancy, and the voucher of the ichthyological collection are presented. DD $=\mathrm{Data}$ deficient; LC $=\mathrm{Least}$ Concern; NT $=$ Nearly threatened; VU $=$ Vulnerable.

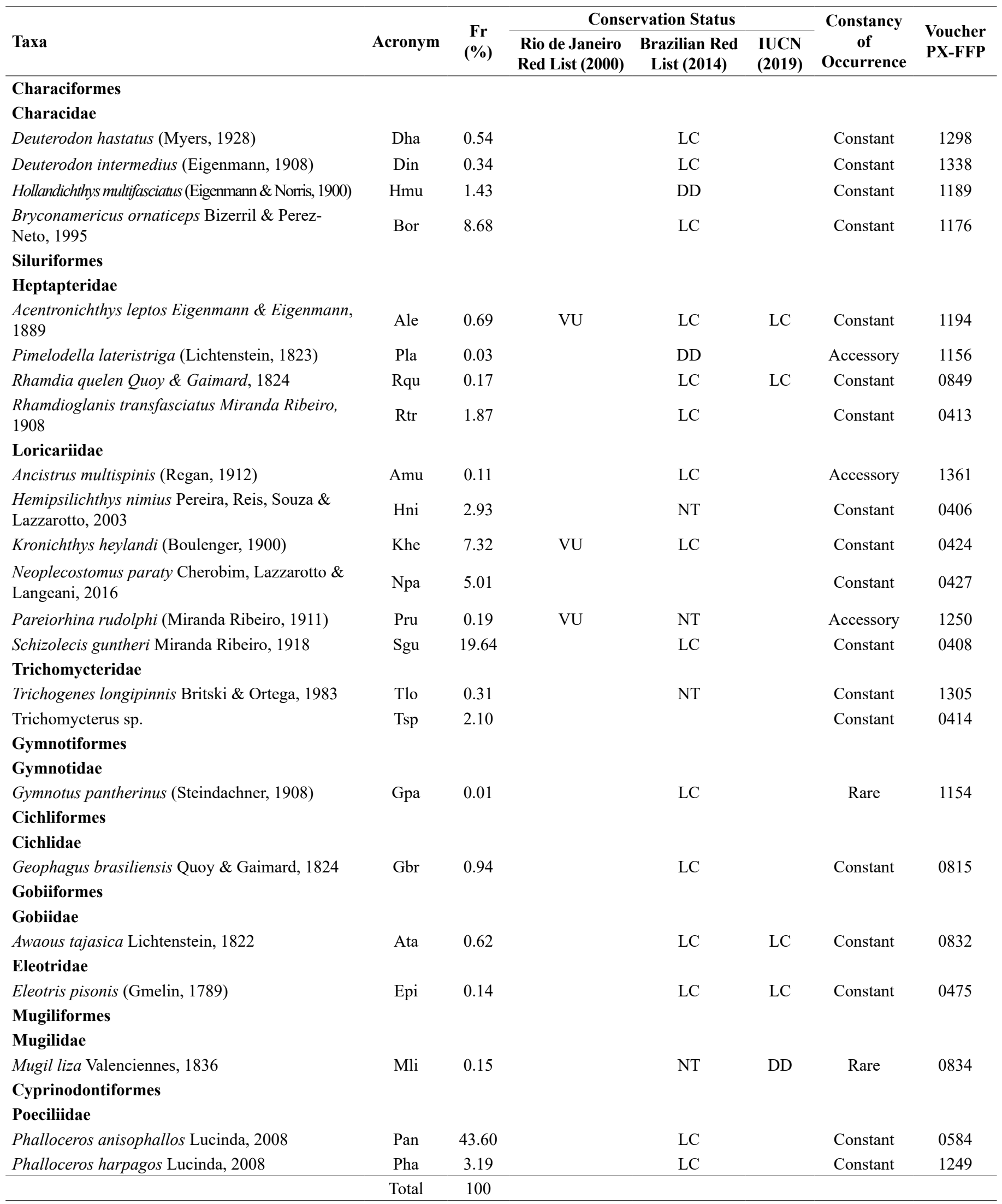


Guimarães, F.V. et al.

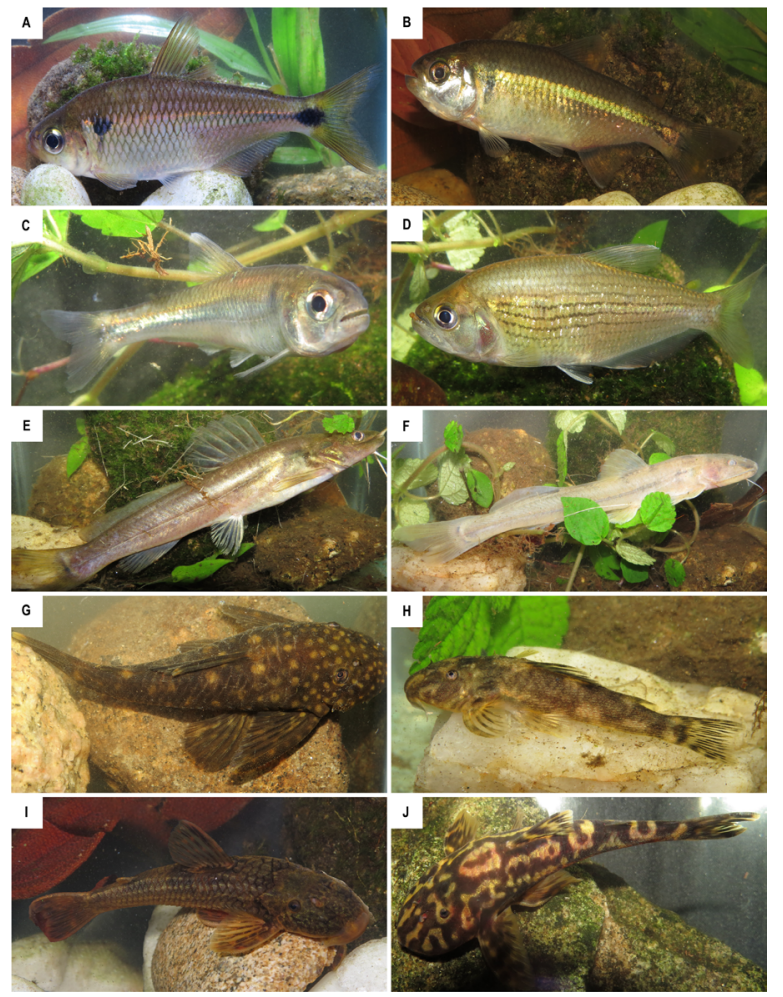

Figure 2. Species sampled in the Perequê-Açu river basin. (A) Deuterodon hastatus; (B) Deuterodon intermedius; (C) Bryconamericus ornaticeps; (D) Hollandichthys multifasciatus; (E) Rhamdia quelen; (F) Rhamdioglanis transfasciatus; (G) Ancistrus multispinis; (H) Hemipsilichthys nimius; (I) Kronichthys heylandi; (J) Neoplecostomus paraty.

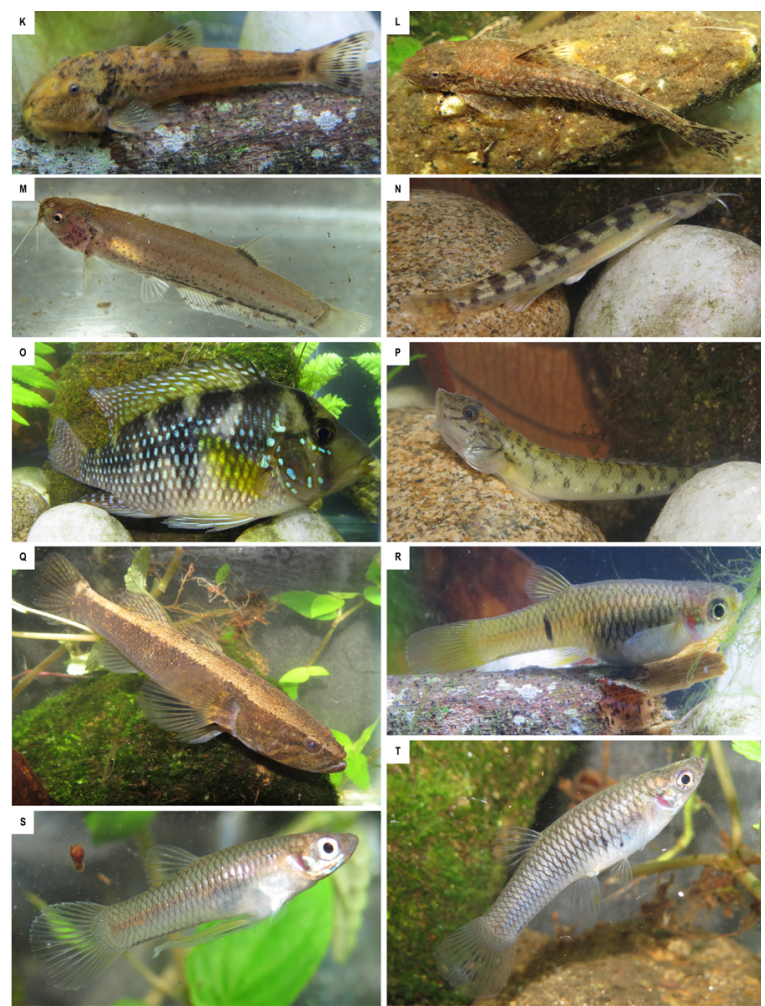

Figure 3. Species sampled in the Perequê-Açu river basin. (K) Pareiorhina rudolphi; (L) Schizolecis guntheri; (M) Trichogenes longipinnis; (N) Trichomyterus sp.; (O) Geophagus brasiliensis; (P) Awaous tajasica; (Q) Eleotris pisonis; (R) female Phalloceros harpagos; (S) male Phalloceros anisophallos; (T) female Phalloceros anisophallos.

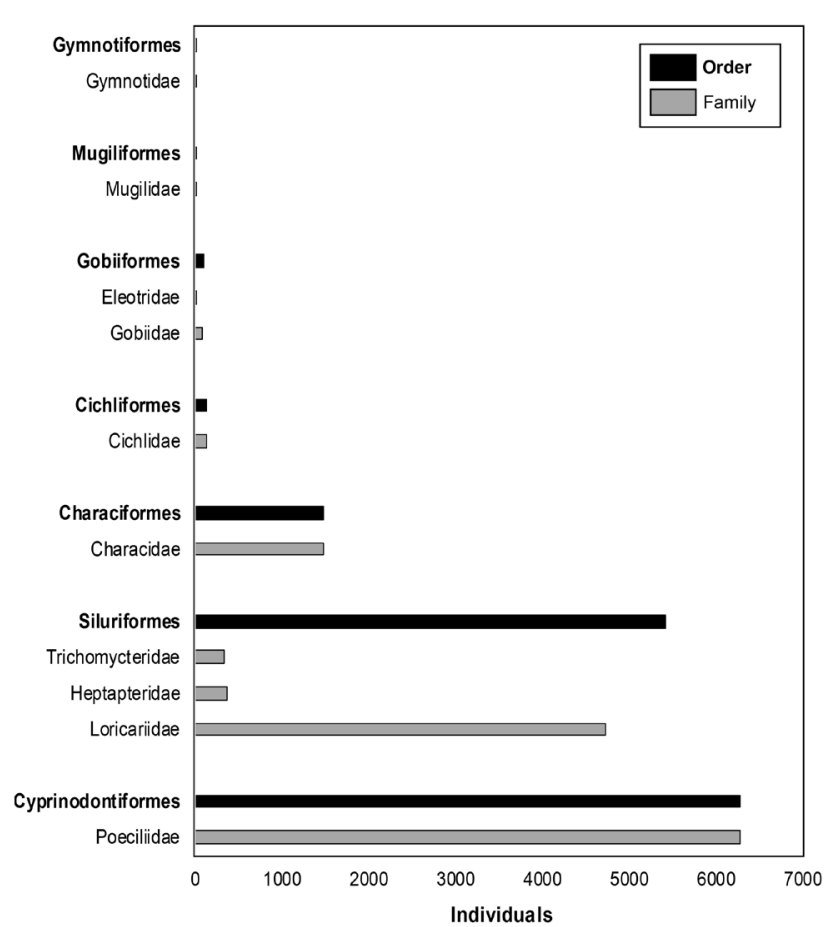

Figure 4. Representativeness graph of the sampled specimens regarding orders and families in the Perequê-Açu river basin.

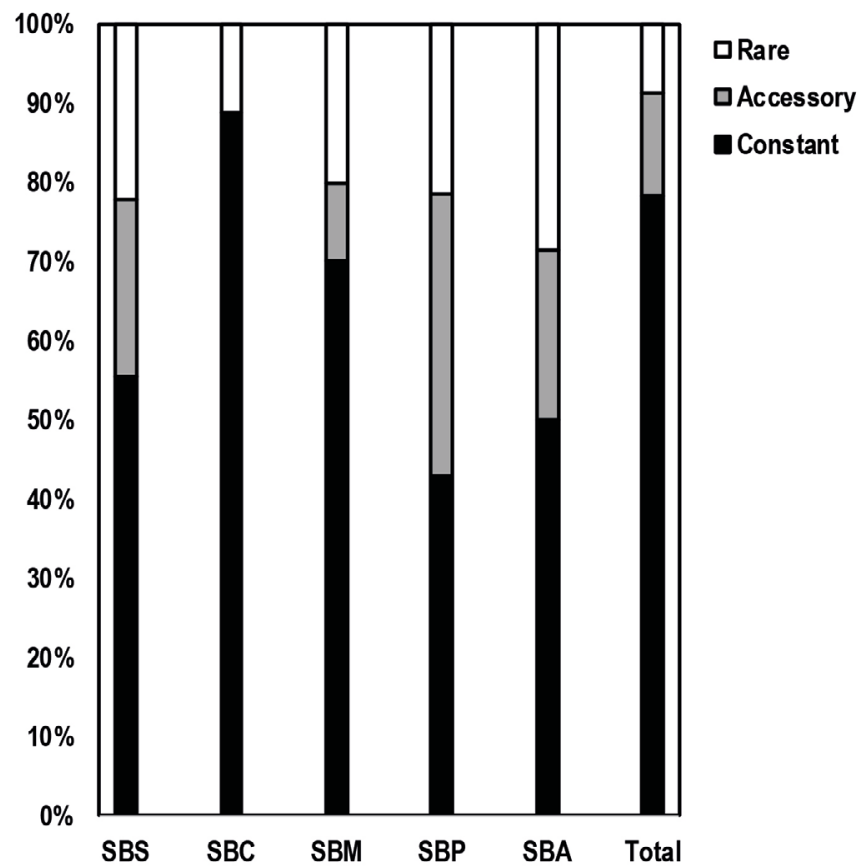

Figure 5. Constancy of occurrence of the Perequê-Açu river basin fish species. $\mathrm{SBS}=$ Sertões river sub-basin; $\mathrm{SBC}=$ Carrasquinho river subbasin; $\mathrm{SBM}=$ Muricana stream sub-basin; $\mathrm{SBP}=$ Pedra Branca river sub-basin; $\mathrm{SBA}=$ Perequê-Açu river sub-basin.

The PERMANOVA result indicated that the spatial distribution of the species is not homogenous along the longitudinal gradient of the drainage $(\mathrm{Df}=2$, Pseudo-F $=4.20, \mathrm{p}=0.0002)$, revealing differences in the composition of species among upstream, midstream, and 
Table 3. Diversity indexes of the sampling sites. $n=$ total individuals. $\mathrm{S}=$ total taxa. $\mathrm{D}=$ dominance index. $\mathrm{H}^{\prime}=$ Shannon index. $\mathrm{J}$ '= Pielou index.

\begin{tabular}{|c|c|c|c|c|c|}
\hline Site & $\mathrm{n}$ & $\mathbf{S}$ & D & $\mathbf{H}^{\prime}$ & $\mathbf{J}^{\prime}$ \\
\hline $\mathrm{S} 1$ & 34 & 2 & 0.701 & 0.451 & 0.651 \\
\hline $\mathrm{S} 2$ & 81 & 5 & 0.494 & 0.831 & 0.517 \\
\hline S3 & 169 & 6 & 0.197 & 1.675 & 0.935 \\
\hline S4 & 87 & 4 & 0.932 & 0.171 & 0.123 \\
\hline S5 & 486 & 7 & 0.451 & 1.009 & 0.518 \\
\hline S6 & 643 & 10 & 0.267 & 1.569 & 0.681 \\
\hline S7 & 150 & 5 & 0.339 & 1.165 & 0.724 \\
\hline S8 & 217 & 9 & 0.458 & 1.109 & 0.505 \\
\hline S9 & 219 & 3 & 0.541 & 0.784 & 0.714 \\
\hline $\mathrm{S} 10$ & 707 & 7 & 0.449 & 1.170 & 0.601 \\
\hline S11 & 442 & 5 & 0.478 & 0.987 & 0.613 \\
\hline $\mathrm{S} 12$ & 448 & 8 & 0.348 & 1.282 & 0.616 \\
\hline S13 & 625 & 7 & 0.385 & 1.135 & 0.583 \\
\hline S14 & 419 & 8 & 0.329 & 1.342 & 0.645 \\
\hline $\mathrm{S} 15$ & 2337 & 6 & 0.516 & 0.913 & 0.510 \\
\hline S16 & 849 & 10 & 0.363 & 1.305 & 0.567 \\
\hline S17 & 161 & 5 & 0.348 & 1.244 & 0.773 \\
\hline S18 & 198 & 7 & 0.246 & 1.484 & 0.762 \\
\hline S19 & 460 & 10 & 0.291 & 1.494 & 0.649 \\
\hline $\mathrm{S} 20$ & 98 & 6 & 0.808 & 0.443 & 0.247 \\
\hline $\mathrm{S} 21$ & 1179 & 12 & 0.407 & 1.167 & 0.470 \\
\hline $\mathrm{S} 22$ & 384 & 10 & 0.298 & 1.383 & 0.601 \\
\hline $\mathrm{S} 23$ & 1520 & 13 & 0.507 & 0.953 & 0.371 \\
\hline $\mathrm{S} 24$ & 1510 & 12 & 0.324 & 1.383 & 0.557 \\
\hline
\end{tabular}

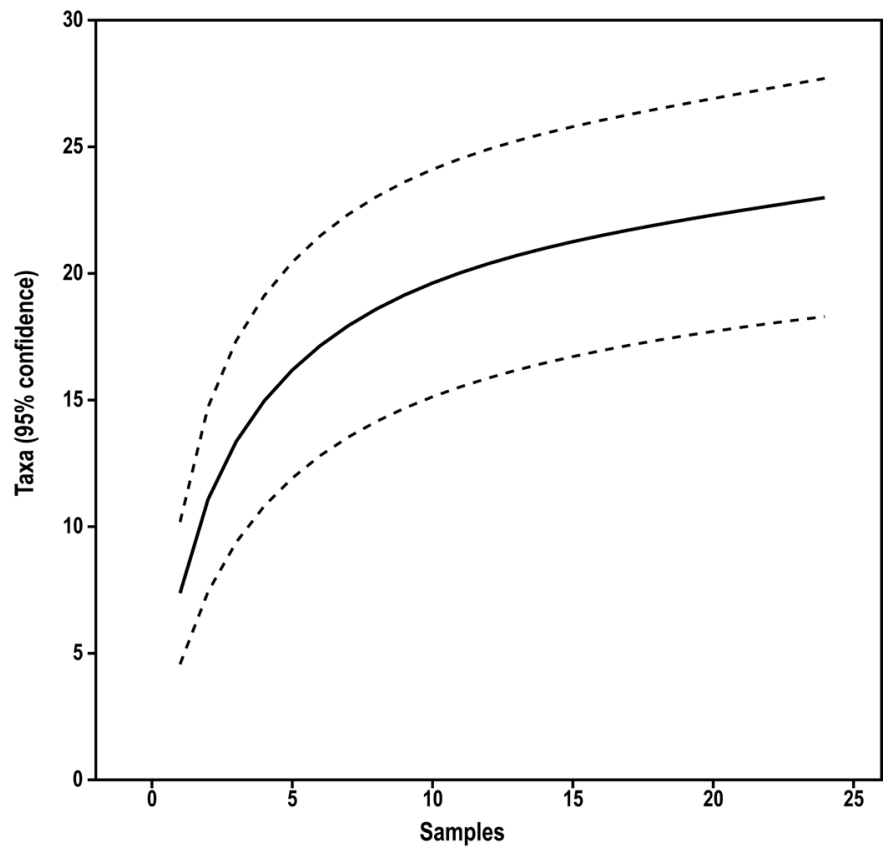

Figure 6. Sample rarefaction curve of the species in the Perequê-açu river basin. The middle line represents the number of sampled species. Dotted lines represent the $95 \%$ bootstrap interval.

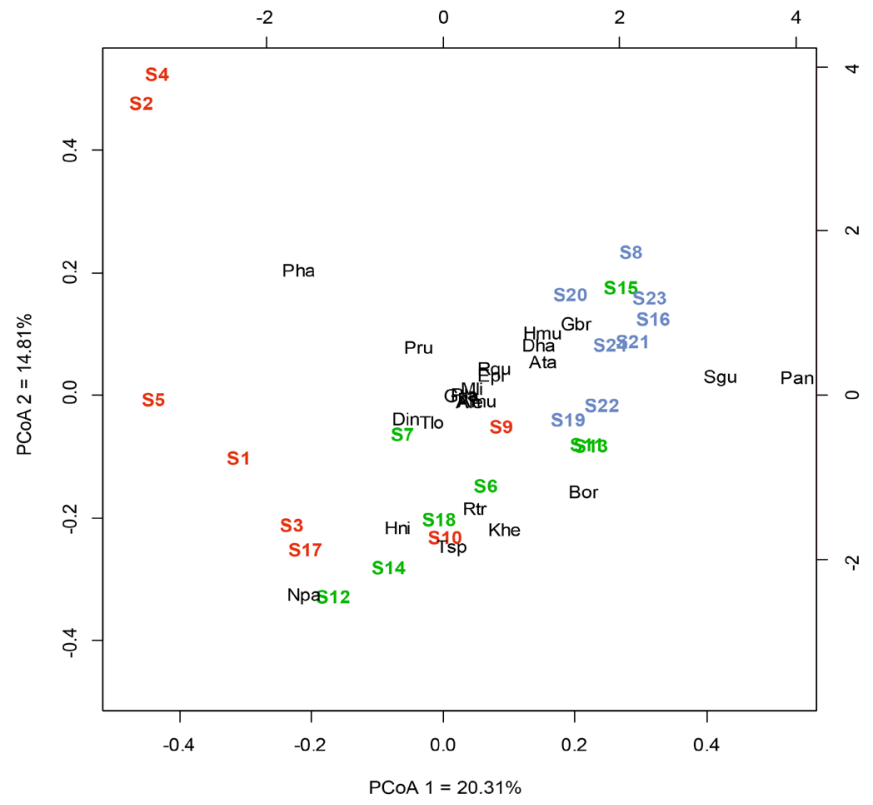

Figure 7. Principal Coordinates Analysis ordination plot, evidencing the composition and distribution of species along upper (red), middle (green) and lower (blue) streams of the Perequê-Açu river basin. List of species abbreviations is presented in Table 2 .

downstream sites. Species richness and abundance tended to increase towards downstream: 12 species in upper streams $(n=1,944), 15$ in middle $(\mathrm{n}=5,262)$ and 18 in lower streams $(\mathrm{n}=6,217)$. The PCoA segregated groups of streams according to their faunistic composition (Figure 7). Neoplecostomus paraty, Phalloceros harpagos, and Pareorhina rudolphi were associated with the upper portions of the basin. Species associated with intermediate portions of the basin, such as Kronichthys heylandi, Rhamdioglanis transfasciatus, and Bryconamericus ornaticeps inhabit both upper and lower portions of this drainage. Schizolecis guntheri and Phalloceros anisophallos, very strongly associated with lower portions of the basin. The analysis also grouped species of low representativity and occurrence in the central part of the graph, such as Gymnotus pantherinus, Pimelodella lateristriga, Rhamdia quelen, and Ancistrus multispinis. The first axis of the graph (PCoA $1=20.31 \%$ ) showed a pattern of decreasing representativeness of siluriform species in the downstream direction, and an increase in the occurrence of Characiformes and Cyprinodontiformes.

SIMPER shows that for the upper portion of the basin (average dissimilarity $=26.1 \%$ ), $K$. heylandi, $N$. paraty, Trichomycterus sp., and $P$. harpagos are the species that most contribute to differentiate these locations from others; in middle streams (average dissimilarity = 48.4\%) P. anisophallos, S. guntheri, B. ornaticeps, Trichomycterus sp., and $R$. transfasciatus; and in lower sites (average similarity: $56.3 \%$ ) P. anisophallos, S. guntheri, K. heylandi, Geophagus brasiliensis, and Awaous tajasica (Table 4). The highest species composition dissimilarity among groups of locations was between upstream and downstream sites, with an average difference of $80.2 \%$. 
Table 4. Contribution (\%) of the most relevant species to dissimilarity in each portion of the basin according to the SIMPER analysis.

\begin{tabular}{lccc}
\hline \multirow{2}{*}{ Species } & \multicolumn{3}{c}{ Groups } \\
\cline { 2 - 4 } & Upstream & Middlestream & Downstream \\
\hline Average similarity (\%) & 26.1 & 48.4 & 56.3 \\
Kronichthys heylandi & 26.5 & & 12.8 \\
Neoplecostomus paraty & 23.8 & & \\
Trichomycterus sp. & 20.7 & 13.7 & \\
Phalloceros harpagos & 17.8 & & 34.2 \\
Phalloceros anisophallos & 3.8 & 23.3 & 26.6 \\
Shizolecis guntheri & & 18.0 & \\
Bryconamericus ornaticeps & & 14.4 & 6.2 \\
Rhamdioglanis transfasciatus & \multicolumn{3}{c}{12.1} \\
Geophagus brasiliensis & \multicolumn{3}{c}{6.2} \\
Awaous tajasica & \multicolumn{3}{c}{ Groups } \\
\hline & Up x & Up x Down & Middle x \\
\cline { 2 - 4 } & Mown \\
\hline Average dissimilarity (\%) & 70.5 & 80.2 & 57.2 \\
\hline
\end{tabular}

\section{Discussion}

It is already well known (e.g. Lowe-McConnell 1999) that the two largest native orders of Otophysi (Characiformes and Siluriformes) from South America are predominant in all Brazilian rivers and streams and, in this case, it was not different. This time, however, since the basin is constituted mostly by mountain streams, which form very steep rapids, the Siluriformes were represented by three times more species than Characiformes, since they fit well in this type of habitat. Loricariidae holds the highest taxonomic diversity of species in the drainage, as their members prefer rapids in bedsides or marginal vegetation in less sloping terrain, recurrent habitats in coastal drainages of the Atlantic Rainforest (Casatti 2005). Among the 12 species of this family, Kronichthys heylandi had the widest distribution in the basin, present in 20 of the 24 sampled locations, from the lowest to the highest site. This was also one of the most abundant species identified by Ferreira and collaborators (2019) in the Itanhaém river, although it was classified as a strongly rhithronic species, that is, more common in the high course of streams. Buck \& Sazima (1995) report that the species is generalist, presenting a wide variety of eating habits and environments where they can live, clinging to rocks, submerged woods, plants and foraging algae, insect larvae, crustaceans and macrophytes throughout the day, which may explain the presence of this taxon at almost all sites of the drainage.

The most abundant species of the family Loricariidae and the order Siluriformes in the samplings was Schizolecis guntheri. This species is widely distributed in coastal basins from the north of Santa Catarina to Rio de Janeiro, adapting to several types of environment with shallow waters and abundant marginal vegetation, regardless of the speed of the water current (Buck \& Sazima 1995, Bizerril \& Primo 2001, Kusma 2013). The latter author reported an interesting type of sexual dimorphism that only occurs in the populations of Schizolecis guntheri in the hydrographic region of Ilha Grande Bay: in other locations females and males of $S$. guntheri have the same color and body size, but in Ilha Grande Bay the males have a bulkier body with many dark spots, as it could be attested in the specimens collected in the present study. Both Kronichthys heylandi and Schizolecis guntheri were also very abundant species in the area studied by Esteves \& Lobón-Cerviá (2001), but the latter showed greater abundance in the rainy season; in Perequê, it was abundant throughout the year, mainly downstream, also differing from the findings of Ferreira et al. (2019). Also in this family, Hemipsilichthys nimius has a narrow distribution, as the other two species of this genus (Buckup 2011): it is endemic to this region, occurring only in the Perequê-Açu and the Taquari river basins, also in Paraty (Pereira et al. 2003, Pereira 2005), where they are relatively common in rapids in middle streams.

The constancy of occurrence analysis revealed that most species in the basin are resident and non-migratory, including when the analysis was applied for each sub-basin. Regarding the constancy of occurrence in the five sub-basins, the one with the highest percentage of rare species was Perequê-Açu, in its final stretch. This result has two reasons: first, it is due to the low representativeness of species that are normally found in the upper and middle reaches of the basin, such as Bryconamericus ornaticeps (Figure 2C), Rhamdioglanis transfasciatus (Figure 2F) and Rhamdia quelen (Figure 2E). Second, as it is the lowest part of the basin, closer to the ocean, it houses peripheral freshwater species like Awaous tajasica and Eleotris pisonis (Medeiros et al. 2019), rarer in our samples. Mugil liza, a marine species, also contributed to this highest rarity value, being found on only one occasion. Vieira (2000) remembers that this index does not consider the abundance of species, only the presence; so, the sampling effort should be distributed throughout all day long (Azevedo-Santos et al. 2019), and also seasonally, to ensure the capture of all species from a site. Alone or associated with the frequency of occurrence, this index can offer an indication of the distribution of species in a given location.

The rarefaction curve indicates that the maximum number of species in the basin may not have been reached, as the curve has not reached an asymptote. This result is in line with the values of species estimators, which also revealed that there is a possible variation in the richness of taxa in the basin. However, the results of both analyses estimate that we were close to the "real" number of species. Possibly, if we had collected in more stretches of the low course of the river, we would have captured species that are commonly obtained in these lowland areas. São-Thiago (1990), in an unpublished dissertation, mentions that she collected almost the same number of species that we collected in Perequê: 22, 13 of which apparently were also collected in the Perequê basin; to be sure, it would be necessary to re-examine the material collected by the author, to update some identifications.

Two species of Phalloceros occur in allopatry in this basin, with a clear preference of $P$. harpagos (Figure 3R) for headwaters and bedside environments, and $P$. anisophallos (Figure 3S, 3T), the most abundant species in the basin, which is a very tolerant species (Mazzoni et al. 2011), found in lowland environments with or without marginal vegetation. P. harpagos was one of the most abundant species in headwater streams from Paranapanema basin (Frota et al. 2020) or in São José dos Dourados and Turvo-Grande basins (Casatti et al. 2012) where, despite the large area collected, only one species of this genus was recorded.

The low representativeness of Gymnotiformes, otherwise, may happen mainly due to the habits of the species. Like other parts of the Brazilian Crystalline Complex, Serra do Mar has about 50\% granitoids 
and 30\% gneisses (Guerra et al. 2013); thus, the riverbed is sandy and shallow, with the bottom formed by large slabs of stones. This type of habitat does not favor the formation of marginal sites and, allied to the slope of the terrain, the water speed does not seem to be adequate to provide a good habitat for species like Gymnotus pantherinus. Nocturnal fishes, during the day they are used to shelter in cracks or holes in clayey or sandy ravines, under stones and submerged vegetation (Crampton \& Albert 2006), places of low occurrence in this basin. The only specimen was found in a small, first-order stream on a flat stretch rich in silt; this stream was receiving remnants of construction works, which contributed to its silting up and possibly to the local extinction of the species.

Following the pattern presented in other drainages (e.g. Corrêa et al. 2015, Silva et al. 2016), the species richness increased in the upstreamdownstream direction, which is related to the increased diversity and complexity of microhabitats. The rise in richness values due to the increase in the types of environments is in line with what was expected by the River Continuum Concept (Vannote et al. 1980). According to Garutti (1988), as they have a smaller volume of water, the headwaters of the streams do not support a large number of individuals and do not favor the emergence of varied microhabitats, which influences species richness. Modifications in the fish assemblages following the longitudinal gradient of a river are expected, as a result of evolutionary adaptations of each species (Silva et al. 2016).

In this way, PERMANOVA, PCoA, and SIMPER results indicate that the composition of the fishes along the catchment is not homogenous. In the upper reaches of the basin, the substrate of rocks, fast-flowing water in rapids areas, and moderate riparian vegetation seem to be favorable to the greater abundances of Loricariidae species such as Neoplecostomus paraty, strongly associated with these environments (Cherobim et al. 2016). On the other hand, these slope headwater habitats limit the great majority of species, mainly Characiformes and Cyprinodontiformes. Middle and lower portions, exhibiting a greater availability of microhabitats, feeding resources, presence of sand and gravel, larger width and depth of watercourses, as well as the increase of marginal vegetation are capable of sustaining more species, especially those with greater abundance and versatility in the basin, such as P. anisophallos, B. ornaticeps, S. guntheri, and $K$. heylandi. The SIMPER result indicates that $P$. anisophallos and $S$. guntheri present an increasing contribution along the longitudinal gradient, being most prominent in the middle and lower reaches of the catchment, places with greater availability of detritus, allochthonous and autochthonous feeding resources (periphyton or animals; Buck \& Sazima 1995, Mazzoni et al. 2010, Ceni \& Barreto 2018).

The strong dissimilarity between upstream and downstream sites in the catchment is a result of the differences between their fauna and the contribution of each species within a group of streams. However, it is worth mentioning that while species such as Hemipsilichthys nimius and Neoplecostomus paraty are abundant in median portions of the basin, their frequencies of occurrence in these locations are lower than those of species such as Bryconamericus ornaticeps and Rhamdioglanis transfasciatus. Clarke (1993) then suggests that species that do not have a consistent abundance within a group are not good indicators for clusters of sites. Thus, drawing a parallel to the results of the analysis of constancy of occurrence, SIMPER deemed relevant for the dissimilarities only constant species, excluding accessory and rare species (even if they present higher abundance). For downstream sites, while Awaous tajasica showed lower abundance than other species in the same group of sites, it stands out because it occurs with more consistency than others.

All three works dealing with the conservation status of this fauna used the IUCN criteria (Mazzoni et al. 2000, ICMBio 2018 and IUCN 2019). Also, the data that is made available in the publication of ICMBio (2018) are the result of a large number of experts who analyzed each one of the Brazilian continental fish species, producing a detailed and comprehensive list. Most of the 23 species were considered as Least Concern (15); four were classified as are considered as nearly threatened (NT) and on two of them the researchers did not find enough data to apply the criteria (so, they were classified as Data Deficient); from the remaining two, one is recently described (Neoplecostomus paraty) and the last is not identified yet (Trichomycterus sp.). In the Rio de Janeiro survey (Mazzoni et al. 2000), Acentronichthys leptos, Kronichthys heylandi and Pareiorhina rudolphi are listed as Vulnerable (VU); in ICMBio (2018), these first two species are listed as Least Concern (LC). Globally (IUCN 2019), four species are categorized as Least Concern (LC, Acentronichthys leptos, Awaous tajasica, Eleotris pisonis, and Rhamdia quelen) and one as Data Deficient (DD, Mugil liza). The advice of ICMBio (2018) is that there should be an effort to expand research to include species about which we do not have sufficient knowledge. Although this seems like something that should be done immediately, in marine and freshwater fish there are 564 species listed as DD. It will take some time for each of these species to be included in a program that involves identifying populations for specimen collections and analysis of taxonomic, trophic and reproductive data, in addition to verifying how structural characters and physiological processes vary over time and in different spaces. There is no guarantee that no species will be lost in the process.

Only seven species are protected under the legislation of the National System of Conservation Units (SNUC), being found within the PNSB: Deuterodon intermedius, Kronichthys heylandi, Neoplecostomus paraty, Pareiohina rudolphi, Phalloceros harpagos, Trichogenes longipinnis, and Trichomycterus sp. Of these species, $K$. heylandi, N. paraty, and Trichomycterus sp. are also in the buffer zone of the park; the remaining 19 species are not included in any protected area. The river's banks in areas outside the park have already been or are being deforested now, giving way to urban advancement. This implies a loss of habitats outside PNSB and its buffer zone that is expected to simplify the structure of communities (Casatti et al. 2012, Miranda 2012, Teresa \& Casatti 2012). This denotes the importance of studies that not only list species or seek to understand how the fish assemblages are organized, but address their conservation status for the improvement of future species lists and implementing practical management actions.

\section{Acknowledgments}

We are grateful to Mr. José Maria Sampaio for technical support; Departamento de Estradas de Rodagem do Estado do Rio de Janeiro, Secretaria de Obras do Governo do Rio de Janeiro and Universidade do Estado do Rio de Janeiro for providing financial and logistical support and to Ricardo Souza Lima for corrections of the English language. Finally, we would like to acknowledge the collecting permit 248/2013 provided by Ibama (Process 02001.003937/2008-18). 


\section{Author Contributions}

Felipe Vieira Guimarães: designed and wrote the manuscript, went to fieldwork, and discussed the results.

Rosana Souza-Lima: designed and wrote the manuscript, went to fieldwork and discussed the results.

Tiago Medeiros de Souza: went to fieldwork and discussed the results.

Richard Rangel Rodrigues: went to fieldwork and discussed the results.

\section{Conflicts of Interest}

The authors declare that they have no conflict of interest related to the publication of this manuscript.

\section{References}

ABELL, R., THIEME, M.L., REVENGA, C., BRYER, M., KOTTELAT, M., BOGUTSKAYA, N., COAD, B., MANDRAK, N., BALDERAS, S.L., BUSSING, W., STIASSNY, M.L.J., SKELTON, P., ALLEN, G.R., UNMACK, P., NASEKA, A., NG, R., SINDORF, N., ROBERTSON, J., ARMIJO, E., HIGGINS, J.Y., HEIBEL, T.J., WIKRAMANAYAKE, E., OLSON, D., LÓPEZ, H.L, REIS, R.E., LUNDBERG, J.G., PÉREZ, M.H.S. \& PETRY, P. 2008. Freshwater ecoregions of the world: a new map of biogeographic units for freshwater biodiversity conservation. Bioscience 58(5): 403-414. https://doi.org/10.1641/B580507

ABILHOA, V., BRAGA, R.R., BORNATOWSKI, H. \& VITULE, J.R.S. 2011. Fishes of the Atlantic Rain Forest Streams: ecological patterns and conservation. In Changing Diversity in Changing Environmental (O. Grillo, ed.). InTech, Rijeka, p.259-282.

AMARAL, L.S.S., BASTOS, A.S.A., SOUZA, M.S.C., FONSECA, M.S., CARVALHO JUNIOR, L., ARAUJO, F.G., NEVES, L.M. 2018. Diversidade de peixes da baía da Ilha Grande: caracterização, padrões espaço-temporais e relações com o habitat. In $7^{\circ}$ Simpósio de Gestão Ambiental e da Biodiversidade (M.A.M de Azevedo, E. Cortines, coords.). Instituto Três Rios, Universidade Federal Rural do Rio de Janeiro, Três Rios, p.27-30.

ANDREATA, J.V., MEURER, B.C., BAPTISTA, M.G.S., MANZANO, F. V., TEIXEIRA, D. E., LONGO, M. M. \& FRERET, N. V. 2002. Composição da assembléia de peixes da Baía da Ribeira, Angra dos Reis, Rio de Janeiro, Brasil. Rev. Bras. Zool 19(4): 1139-1146. https://doi.org/10.1590/S010181752002000400019

AZEVEDO-SANTOS, V.M., BRITSKI, H.A., OLIVEIRA, C. \& BENINE, R.C. 2019. Ichthyofauna of streams of the Rio Sapucaí basin, upper Rio Paraná system, Minas Gerais, Brazil. Biota Neotrop. 19(1): e20180617. http:// dx.doi.org/10.1590/1676-0611-bn-2018-0617 (last access in 28/05/2020)

BIZERRIL, C.R.S.F. 1994. Análise taxonômica e biogeográfica da ictiofauna de água doce do leste brasileiro. Acta Biol. Leopoldensia 16(1): 51-80.

BIZERRIL, C.R.S.F. \& PRIMO, P.B.S. 2001. Peixes de Águas Interiores do Estado do Rio de Janeiro. 1 ed. Femar - Semads, Rio de Janeiro.

BRASIL. 2004. Decreto $N^{\circ}$ 5.092, de 21 de maio de 2004. Presidência da República do Brasil, Brasília. Disponível em: < http://www.planalto.gov. br/ccivil_03/_ato2004-2006/2004/decreto/d5092.htm>

BUCK, S. \& SAZIMA, I. 1995. An assemblage of mailed catfishes (Loricariidae) in southeastern Brazil: distribution, activity and feeding. Ichthyol. Explor. Fresh. 6(4): 325-332.

BUCKUP, P.A. 2011. The Eastern Brazilian Shield. In Historical Biogeography of Neotropical Freshwater Fishes (J.S. Albert \& R.E. Reis, eds.). University of California Press, California, p.203-210.

BUCKUP, P.A., MENEZES, N.A. \& GHAZZI, M.S. 2007. Catálogo das espécies de peixes de água doce do Brasil. 1 ed. Museu Nacional, Rio de Janeiro.

CASATTI, L. 2005. Fish assemblage structure in a first order stream, Southeastern Brazil: longitudinal distribution, seasonality, and microhabitat diversity. Biota Neotrop. 5(1): 1-9. https://doi.org/10.1590/S167606032005000100009 (last access in 29/05/2020)
CASATTI, L., TERESA, F.B., GONÇALVES-SOUZA, T., BESSA, E., MANZOTTI, A.R., GONÇALVES, C.S. \& ZENI, J.O. 2012. From forests to cattail: how does the riparian zone influence stream fish? Neotrop. Ichthyol. 10(1): 205-214. https://doi.org/10.1590/S1679-62252012000100020

CAVALHEIRO, L.W. \& FIALHO, C.B. 2020. Fishes community composition and patterns of species distribution in Neotropical streams. Biota Neotrop. 20(1): e20190828. http://dx.doi.org/10.1590/1676-0611-BN-2019-0828 (last access in 25/06/2020)

CENI, G. \& BARRETO, A.P. 2018. Reproductive aspects of Schizolecis guntheri (Loricariidae: Hypoptopomatinae), in an Atlantic Forest stream, Southern Brazil. Pan-Am. J. Aquat. Sci. 13(4): 282-288.

CHAO, A. 1984. Non-parametric estimation of the number of classes in a population. Scand. J. Stat. 11: 265-270.

CHEROBIM, A.M., LAZZAROTTO, H. \& LANGEANI, F. 2016. A new species of the catfish Neoplecostomus (Loricariidae: Neoplecostominae) from a coastal drainage in southeastern Brazil. Neotrop. Ichthyol. 14(4): e160015. https://doi.org/10.1590/1982-0224-20160015

CLARKE, K.R. 1993. Non-parametric multivariate analyses of changes in community structure. Austral Ecol. 18(1): 117-143.

CLARKE, K.R. \& GORLEY, R.N. 2006. PRIMER v6: user manual/tutorial. PRIMER-E, Plymouth.

CORRÊA. F., OLIVEIRA, E.F., TUCHTENHAGEN, T., POUEY, J. \& PIEDRAS, S. 2015. Ichthyofauna of the hydrographic basin of the Chasqueiro Stream (Mirim Lagoon system, southern Brazil): generating subsidies for conservation and management. Biota Neotrop. 15(4): e0006. https://doi.org/10.1590/16760611-BN-2015-0006 (last access in 28/05/2020)

CRAMPTON, W.G.R. \& ALBERT, J.S. 2006. Evolution of electric signal diversity in gymnotiform fishes. In Communication in Fishes (F. Ladich, S.P. Collin, P. Moller \& B.G. Kapoor, eds.). Science Publishers, Enfield, p.641-725.

CREED, J.C., OLIVEIRA, A.E.S., PIRES, D.O., FIGUEIREDO, M.A. de O, FERREIRA, C.E.L., VENTURA, C.R.R., BRASIL, A.C., YOUNG, P.S., ABSALÃO, R.S., PAIVA, P.C., CASTRO, C.B., SEREJO \& C. RAP. 2007. Ilha Grande - um Levantamento da Biodiversidade: Histórico e Conhecimento da Biota. In Biodiversidade Marinha da Baía da Ilha Grande (J.C. Creed, D.O. Pires \& M.A. de O. Figueiredo. eds.). Ministério do Meio Ambiente/Secretaria de Biodiversidade e Florestas, Brasília, p.19-39.

DAJOZ, R. 1983. Ecologia geral. 4 ed. Editora Vozes, Petrópolis.

DRAY, S., BAUMAN, D., BLANCHET, G., BORCARD, D., CLAPPE, S., GUENARD, G., JOMBART, T., LAROCQUE, G., LEGENDRE, P., MADI, N. \& WAGNER, H.W. 2020. adespatial: Multivariate Multiscale Spatial Analysis. R package version 0.3-8. Available at: https://CRAN.R-project. org/package=adespatial (last access in 25/06/2020)

EFRON, B. 1979. Bootstrap methods: Another look at the jackknife. Ann. Stat. 7(1): 1-26. https://doi.org/10.1214/aos/1176344552

ESTEVES, K.E. \& LOBÓN-CERVIÁ, J. 2001. Composition and trophic structure of a fish community of a clear water Atlantic rainforest stream in southeast Brazil. Environ. Biol. Fishes 62(4): 429-440. https://doi. org/10.1023/A:1012249313341

FERREIRA, C.E.L., FERREIRA, C.G.W., RANGEL, C.A., MENDONCA, J.P., GERHARDINGER, L.C., CARVALHO FILHO, A., GODOY, E.A., LUIZ JR, O. \& GASPARINI, J.L. Peixes Recifais. In Biodiversidade Marinha da Baía da Ilha Grande (J. C. Creed, D.O. Pires, D.O, M.A. de O. Figueiredo, eds.). Ministério do Meio Ambiente/Secretaria Nacional de Biodiversidade e Florestas, Brasília, p. 291-322.

FERREIRA, F.C., SOUZA, U.P., CETRA, M. \& PETRERE JÚNIOR, M. 2019. Rhithronic and potamonic fishes coexist in wadeable streams under distinct metacommunity processes. Ecol. Freshw. Fish, 28(1): p. 85-96. https://doi. org/10.1111/eff.12433

FORMIGA-JOHNSSON, R.M. \& IKEMOTO, S.M. 2015. Diagnóstico do setor costeiro da Baía da Ilha Grande subsídios à elaboração do zoneamento ecológicoeconômico costeiro. Volume I. Governo do Estado do Rio de Janeiro, Secretaria de Estado do Ambiente, Instituto Estadual do Ambiente, Rio de Janeiro.

FRICKE, R., ESCHMEYER, W.N. \& VAN DER LAAN, R. 2020. ESCHMEYER'S CATALOG OF FISHES: GENERA, SPECIES, REFERENCES. http://researcharchive.calacademy.org/research/ ichthyology/catalog/fishcatmain.asp (last access in 24/06/2020). 
FROTA, A., MESSAGE, H.J., OLIVEIRA, R.C. de, BENEDITO, E. \& GRAÇA, W.J. da. 2019. Ichthyofauna of headwater streams from the rio Ribeira de Iguape basin, at the boundaries of the Ponta Grossa Arch, Paraná, Brazil. Biota Neotrop. 19(1), e20180666. https://doi.org/10.1590/1676-0611bn-2018-0666 (last access in 15/07/2020)

FROTA, A., OTA, R.R., DEPRÁ, G.C., GANASSIN, M.J.M. \& GRAÇA, W.J. da. 2020. A new inventory for fishes of headwater streams from the rio das Cinzas and rio Itararé basins, rio Paranapanema system, Paraná, Brazil. Biota Neotrop. 20(1): e20190833. http://dx.doi.org/10.1590/1676-0611$\mathrm{BN}-2019-0833$

GAELZER, L.R., MACHADO, G.R. \& NOGUCHI, R.C. 2007. Peixes de praias arenosas. In Biodiversidade marinha da Baía de Ilha Grande (J.C. Creed, D.O. Pires, M.A.O. Figueiredo, eds.). Ministério do Meio Ambiente, Brasília, p.325-348.

GARUTTI, V. 1988. Distribuição longitudinal da ictiofauna em um córrego da região noroeste do Estado de São Paulo, bacia do rio Paraná. Rev. Bras. Biol., 48(4): 747-759.

GOTELLI, N.J. \& COLWELL, R.K. 2011. Estimating Species Richness. In Biological Diversity: Frontiers in Measurement and Assessment (A. E. Magurran, \& B. J. McGill, eds.). Oxford University Press, Oxford, p.39-54.

GUERRA, A.J.T., BEZERRA, J.F.R., JORGE, M.C.O. \& FULLEN, M.A. 2013. The geomorphology of Angra dos Reis and Paraty municipalities, southern Rio de Janeiro State. Rev. Geonorte 4(13): 1-21.

GUimarÃES, A.E, GENTILE, C., LOPES, C.M., SANT'ANNA, A. \& JOVITA, A.M. 2000. Ecologia de mosquitos (Diptera: Culicidae) em áreas do Parque Nacional da Serra da Bocaina, Brasil. I. Distribuição por hábitat. Rev. Saúde Pública, 34(3): 243-250. http://dx.doi.org/10.1590/ S0034-89102000000300006

HAMMER, Ø, HARPER, D.A.T. \& RYAN, P.D. 2001. PAST: Paleontological Statistics Software Package for Education and Data Analysis. Palaeontol. Electron. 4(1) 1-9.

IBAMA - Instituto Brasileiro do Meio Ambiente e dos Recursos Renováveis. 2001. Plano de Manejo do Parque Nacional da Serra da Bocaina. http://www. paraty.com.br/bocaina/index.htm (last access in 25/06/2020)

ICMBIO - Instituto Chico Mendes de Conservação da Biodiversidade. 2018. Livro Vermelho da Fauna Brasileira Ameaçada de Extinção. Volume VI Peixes. 1 ed. ICMBIO, Brasília.

IUCN RED LIST OF THREATENED SPECIES VERSION 2019.2. https:// www.iucnredlist.org/ (last access in 29/05/2020).

KREBS, C.J. 1999. Ecological Methodology. 2 ed. Longman, Harlow.

KUSMA, C.M. 2013. Revisão Taxonômica de Schizolecis Britski \& Garavello, 1984 (Loricariidae: Hypoptopomatinae). Dissertação de Mestrado, Pontifícia Universidade Católica do Rio Grande do Sul, Porto Alegre.

LANGEANI, F., BUCKUP, P.A., MALABARBA, L.R., PY-DANIEL, L.H.R., LUCENA, C.A.S., ROSA R.S., ZUANON, J.A.S., LUCENA, Z.M.S., BRITTO, M.R., OYAKAWA, O.T. \& GOMES-FILHO, G. 2009. Peixes de Água Doce. In Estado da Arte e perspectivas para a Zoologia no Brasil (R.M. Rocha, \& W.A.P. Boeger, eds.). Editora da UFPR, Curitiba, p.209-230.

LEGENDRE, P. \& LEGENDRE, L. 1998. Numerical ecology. Elsevier Science B. V., Amsterdam

LOWE-McCONNELL, R.H. 1999. Estudos ecológicos de comunidades de peixes tropicais. 1 ed. EDUSP, São Paulo.

MAGURRAN, A.E. 2004. Measuring Biological Diversity. 1 ed. Blackwell Publishing, Malden.

MAZZONI, R., ARAÚJO, R.R.S., SANTOS, G.C.T. \& IGLESIAS-RIOS, R. 2010. Feeding ecology of Phalloceros anisophallos (Osteichthyes: Cyprinodontiformes) from Andorinha Stream, Ilha Grande, Brazil. Neotrop. Ichthyol. 8(1): 179-182. https://doi.org/10.1590/S1679-62252010000100021

MAZZONI, R., BIZERRIL, C.R.F.S., BUCKUP, P.A., FILHO, O.C.M., FIGUEIREDO, C.A., MENEZES, N.A., NUNAM, G.W. \& TANIZAKIFONSECA, K. 2000. Peixes. In A fauna ameaçada de extinção do estado do Rio de Janeiro (H.G. Bergallo, C.F.D. Rocha, M.A.S. Alves \& M.V. Sluys, eds.). UERJ \& FAPERJ, Rio de Janeiro, p. 63-76.
MAZZONI, R., NOVAES, V.C. \& IGLESIAS-RIOS, R. 2011. Microhabitat use by Phalloceros harpagos Lucinda (Cyprinodontiformes: Poeciliidae) from a coastal stream from Southeast Brazil. Neotrop. Ichthyol. 9(3): 665-672. https://doi.org/10.1590/S1679-62252011005000027

MEDEIROS, L.S., RAMOS, T.P.A., SILVA, M.J., PAIVA, R.E.C., LIRA, M.G.A. \& LIMA, S.M.Q. 2019. Ichthyofauna of Trairí river basin, Rio Grande do Norte state, northeastern Brazil: a century after the study of the naturalist Edwin Starks in the Papari lagoon. Pap. Avulsos Zool. 59, e20195901. https://doi.org/10.11606/1807-0205/2019.59.01

MELO, A.S. 2008. O que ganhamos 'confundindo' riqueza de espécies e equabilidade em um índice de diversidade? Biota Neotrop. 8(3): 21-27. https:// doi.org/10.1590/S1676-06032008000300001 (last access in 20/05/2020)

MIRANDA, J.C. 2012. Ameaças aos peixes de riachos da Mata Atlântica. Natureza on line 10(3): 136-139.

PARADIS, E. \& SCHLIEP, K. 2019. Ape 5.0: an environment for modern phylogenetics and evolutionary analyses in R. Bioinformatics, 35(3): 526-528.

PEREIRA, E.H.L. 2005. Resurrection of Pareiorhaphis Miranda Ribeiro, 1918 (Teleostei: Siluriformes: Loricariidae), and description of a new species from the rio Iguaçu basin, Brazil. Neotrop. Icthyol. 3(2): 271-276. http:// dx.doi.org/10.1590/S1679-62252005000200004

PEREIRA, E.H.L., REIS, R.E., SOUZA, P.F.M. \& LAZZAROTTO, H. 2003. A new species of the loricariid catfish genus Hemipsilichthys from southern Rio de Janeiro coastal rivers, southeastern Brazil (Teleostei: Siluriformes). Zootaxa, 285(1): 1-10. http://dx.doi.org/10.11646/zootaxa.285.1.1

PIELOU, E.C. 1975. Ecological diversity. 1 ed. Wiley, New York.

QGIS DEVELOPMENT TEAM. 2020. QGIS Geographic Information System. Open Source Geospatial Foundation Project. http://qgis.osgeo.org (last access in 15/03/2020)

R CORE TEAM. 2019. R: A language and environment for statistical computing. R Foundation for Statistical Computing, Vienna, Austria. https://www.Rproject.org/ (last access in 20/06/2020)

REIS, R.E., ALBERT, J.S., DARIO, F. Di., MINCARONE, M.M., PETRY, P. \& ROCHA, L.A. 2016. Fish biodiversity and conservation in South America. J. Fish Biol. 89(1): 12-47. https://doi.org/10.1111/jfb.13016

RIBEIRO, A.C. 2006. Tectonic history and the biogeography of the freshwater fishes from the coastal drainages of eastern Brazil: an example of faunal evolution associated with a divergent continental margin. Neotrop. Ichthyol. 4(2): 225-246.

SÃO-THIAGO, H. 1990. Composição e distribuição longitudinal da ictiofauna do Rio Parati-Mirim (RJ) e aspectos sobre a reprodução das principais espécies. Dissertação de Mestrado, Universidade Federal do Rio de Janeiro, Rio de Janeiro.

SILVA, J.C., GUBIANI, É.A., PIANA, P.A. \& DELARIVA, R L. 2016. Effects of a small natural barrier on the spatial distribution of the fish assemblage in the Verde River, Upper Paraná River Basin, Brazil. Braz. J. Biol. 76(4): 851-863. https://doi.org/10.1590/1519-6984.01215

SIMPSON, E.H. 1949. Measurement of diversity. Nature, 163(1): 688. https:// doi.org/10.1038/163688a0

TERESA, F.B. \& CASATTI, L. 2012. Influence of forest cover and mesohabitat types on functional and taxonomic diversity of fish communities in Neotropical lowland streams. Ecol. Freshw. Fish 21(3): 433-442. https:// doi.org/10.1111/j.1600-0633.2012.00562.x

VANNOTE, R.L., MINSHALL, G.W., SEDELL, J.R. \& CUSHING, C.E. 1980. The river continuum concept. Can. J. Fish. Aquat. Sci. 37(1): 130-137. http:// dx.doi.org/10.1139/f80-017

VIEIRA, I. 2000. Frequência, constância, riqueza e similaridade da ictiofauna da bacia do rio Curuá-Una, Amazônia. Rev. Bras. Zoociênc. 2(2): 51-76.

Received: $23 / 07 / 2020$

Revised: 12/01/2021

Accepted: $15 / 01 / 2021$

Published online: 05/03/2021 